\title{
RELATIONSHIP BETWEEN THE ISCHIOTIBIAL AND PARAVERTEBRAL MUSCLES AND LOW BACK PAIN
}

\author{
RELAÇÃO ENTRE OS MÚSCULOS ISQUIOTIBIAIS E PARAVERTEBRAIS COM A LOMBALGIA \\ RELACIÓN ENTRE LOS MÚSCULOS ISQUIOTIBIALES Y PARAVERTEBRALES CON \\ LA LUMBALGIA
}

HARON SILVA DORTA ${ }^{1}$

1. Universidade Federal de São Paulo, Escola Paulista de Medicina, UNIFESP-EPM, São Paulo, SP, Brazil.

\begin{abstract}
Low back pain or lumbago is a painful condition that affects an increasing number of people around the world and has numerous causal factors. Among these factors, the most distinctive are muscle imbalances, weakness of paravertebral muscles and shortening of ischiotibial muscles. The role of these muscle groups is still controversial and not fully explained in the literature. Thus, a survey was conducted in the SciELO, LILACS, MEDLINE, and PubMed databases in the last decade (2003-2013), using as keywords: hamstrings, low back pain, lumbago, and paravertebral. The works found confirm that, according to the methodology, weakness in paravertebral muscles is of great importance to the development of low back pain as well as the shortening of the ischiotibial muscles, which are directly related to this factor.
\end{abstract}

Keywords: Low back pain; Back muscles; Paraspinal muscles.

\section{RESUMO}

A dor lombar ou lombalgia é um quadro álgico que acomete um número cada vez maior de pessoas em todo o mundo e tem inúmeros fatores causais. Entre esses fatores, os que mais se destacam são desequilíbrios musculares, fraqueza dos paravertebrais e encurtamentos de isquiotibiais. O papel desses grupos musculares ainda é controverso e não está totalmente esclarecido na literatura. Desta maneira, foi realizada uma pesquisa nas bases de dados SciELO, LILACS, MEDLINE e PUBMED na última década (2003 a 2013), utilizando-se como descritores: isquiotibiais, lombalgia, dor lombar e paravertebrais. Os trabalhos encontrados confirmam que, de acordo com a metodologia empregada, a fraqueza dos músculos paravertebrais é de grande relevância para o desenvolvimento das dores lombares, assim como os encurtamentos dos isquiotibiais, que estão diretamente relacionados a esse fator.

Descritores: Dor lombar; Músculos do dorso; Músculos paraespinais.

\section{RESUMEN}

El dolor lumbar o lumbago es una condición dolorosa que afecta a un número creciente de personas en todo el mundo y tiene numerosos factores causales. Entre estos factores, los que se destacan son los desequilibrios musculares, debilidad de los músculos paravertebrales y el acortamiento de los músculos isquiotibiales. El papel de estos grupos musculares aún es controvertido y no se explican completamente en la bibliografía. Por lo tanto, se realizó una encuesta en las bases de datos SciELO, LILACS, MEDLINE y PubMed en la última década (2003-2013), utilizando como descriptores: isquiotibiales, dolor de la región lumbar, lumbago y paravertebrales Los trabajos encontrados confirman que, de acuerdo con la metodología empleada, la debilidad de los músculos paravertebrales es de gran importancia para el desarrollo de dolor lumbar, así como el acortamiento de los isquiotibiales, los cuales están directamente relacionados con este factor.

Descriptores: Dolor de la región lumbar; Músculos de la espalda; Músculos paraespinales.

\section{INTRODUCTION}

Low back pain or lumbago is a painful condition that mainly affects the lumbosacral region ${ }^{1,2}$ between vertebrae L1 and S1. Its multiple causes are related to numerous factors such as physical inactivity, being overweight, muscular weakness, postural changes, muscle shortening, and muscle chain imbalance, among others. ${ }^{3-7}$ Among the musculatures that stand out for these causal factors are the ischiotibial and paravertebral antigravitational postural muscle groups. The correlation between the performance of these muscle groups and low back pain is controversial. The objective of this study is to determine whether this correlation exists between the ischiotibial and paravertebral muscles and low back pain, to help elucidate the causal factors and thus improve the treatment of these cases.

\section{Low back pain}

Chronic low back pain can be defined as a persistent pain lasting for more than 12 weeks in the lumbar and sacral regions of the spine. ${ }^{1}$ Low back pain characteristically affects the region below the last costal arch and above the inferior gluteal folds, and may or may not radiate to the lower limbs. ${ }^{2}$ It is known that low back pain can be classified as either primary or secondary. The primary type may or may not include neurological, mechanical-degenerative, non-mechanical, inflammatory, infectious, metabolic, and neoplastic involvement, while secondary 
lumbago is correlated with an association to systemic diseases. ${ }^{3}$ Low back pain is caused by multiple factors, but the existence of muscle imbalances in the extensor and flexor muscle chains of the spine are strong indications for the development of chronic low back pain, ${ }^{4}$ and there is also an important relationship between the shortening of the ischiotibial and paravertebral muscles and low back pain. ${ }^{5}$

Low back pain is associated with poor trunk and hip flexibility correlated with the paravertebral and ischiotibial muscle groups, which are intimately related to a lack of flexibility. ${ }^{5}$ Good flexibility and good muscular balance are necessary to maintain an erect posture and to resist the existing gravitational, external, and intrinsic forces. Currently, it is becoming increasingly difficult to adopt a balanced posture without additional stress to the structures that sustain the spine, mainly as a result of our daily lives where man is exposed to sudden changes of position and/or spends most of his time sitting. ${ }^{2,6}$

In the seated position, there is an increase load of weight in the region of ischial tuberosity region and on the adjacent soft tissue with more pressure in one specific area than in another. This incorrect posture favors the development of shortened ischiotibial and iliopsoas muscles, increasing the chances of a higher degree of lumbar lordosis and stress to the stabilizing structures, as well as the intense contraction of the paravertebral muscles in their attempt to maintain an upright posture, the reduction of flexibility, and a higher load on the intervertebral discs, all of which favor the development of low back pain and pathologies of the vertebral discs. ${ }^{2-10}$

\section{The ischiotibial muscles}

The ischiotibials are a group of three muscles: the biceps femoris, the semitendinosus, and the semimembranosus, which are located in the posterior thigh. ${ }^{10-14}$ Their origin attachment point is the ischial tuberosity and their insertion point is the posterior face of the condyles of the tibia (hence the name ischiotibials). Their functions are hip extension, knee flexion, and retroversion of the pelvis. This group has an important influence on anterior-posterior pelvic tilt, affecting the mechanics of the lumbar region indirectly. ${ }^{11-15}$ In the sitting position, the tendons of the ischiotibials are slack and shorten to correct this slackness, increasing the tension in the ischiotibials and decreasing flexibility. Decreased flexibility of this muscle group can cause postural deviations, such as posterior pelvic tilt, which affects gait and causes pain in the joints and muscles of the lower limbs and, consequently, their misalignment. ${ }^{11-16}$

\section{The paravertebral muscles}

The paravertebrals are a group of muscles that consist of the semispinalis, multifidus, rotatores, interspinales, and intertransversarii muscles. They are located in the posterior vertebral spine and their function is the keep the torso upright while we are standing or sitting. ${ }^{17-22}$

There is a close relationship between the paravertebral muscles and low back pain. Studies to evaluate the muscle strength of patients with mechanical low back pain have found severe hypotrophy of the paravertebral musculature of these patients among their results, showing the close relationship between mechanical low back pain and weakness of the paravertebrals. 3,6,23

This relationship corroborates studies evaluating low back pain in pregnant women, in whom hyperlodotic and biomechanical postural changes during pregnancy affect mainly the ischiotibial, paravertebral, and abdominal muscles. ${ }^{24,25}$

\section{DISCUSSION}

The ischiotibials are a group of three muscles located in the posterior region of the thigh, consisting of the semitendinosus, semimembranosus, and biceps femoris. ${ }^{15,16}$ Santos et al. ${ }^{26}$, in their study of these muscles, found that shortening of the ischiotibials was directly related to pain in the lumbar region. The flexibility of the ischiotibial muscles is important for postural balance and to the maintenance of the total range of motion of the knee and hip. ${ }^{19,20}$ Another very important factor is lack of physical activity, directly or indirectly related to back pain due to the shortening of muscles and overloads on the spine, making individuals more susceptible to low back pain., 30-24

Sedentary individuals who had pain in the lumbar region and underwent a program of stretching followed by muscle strengthening experienced an improvement in body posture and a reduction in the incidence of lumbar pain at the end of treatment. ${ }^{3,23-25}$ A profile of low back pain is related to the shortening of the ischiotibial muscles. ${ }^{5}$ These results were also confirmed in pregnant women, who had decreased low back pain following a program of stretching of the ischiotibials. ${ }^{26}$

Glaner, ${ }^{27}$ who conducted a bibliographical review, concluded that stretching exercises are recommended for patients with low back pain, and are beneficial in both injury prevention and pain reduction in patients with chronic low back pain. ${ }^{24-27}$

The primary function of the paravertebral muscles is to create enough torque strength to sustain posture and enable movement, but they also have the critical role of ensuring the stability of the lumbar spine. ${ }^{28} \mathrm{~A}$ study conducted with patients with chronic low back pain found that their extensor muscles were weaker than their flexor muscles. ${ }^{28}$ Muscle weakness is associated with lack of physical activity, hypotrophy of the paravertebral muscles, ${ }^{29,30}$ and changes in neuromotor control, ${ }^{31-33}$ such as delays in anticipatory adjustments of the paravertebral and transverse abdominal muscles, as well as proprioceptive deficits and imbalance. ${ }^{34}$

Postural changes, reduced spinal mobility, obesity, shortening of the ischiotibial muscles in the posterior chain, and weakness of the paravertebral muscles are associated with profiles of chronic low back pain. ${ }^{32}$ The flexor and extensor muscles play the important role of protecting the passive structures of the vertebral spine. Hypotrophy resulting from their disuse and from prolonged duration of certain positions, or also from fatigue from repetitive movements, cause the transfer of excessive loads and provoke chronic low back pain. ${ }^{35,36}$ The relationship between the action of the flexors and extensors of the spine is very important in movements of muscle strength and resistance for individuals with chronic low back pain. ${ }^{37}$

Studies have been conducted offering evidence that exercises for stabilization of the paravertebral muscles reduce low back pain. ${ }^{38,39}$ Trunk strengthening exercises are proven effective for patients with low back pain when results were compared to a control group that did not perform the exercises. ${ }^{40}$ Also, strengthening exercises and aerobic exercises promote a quicker return to work in individuals with chronic low back pain. ${ }^{27}$ Individuals with lumbar dysfunction demonstrate reduced resistance of the paravertebral musculature, possibly caused by changes in the pattern of motor control and by prolonged overload of the passive support system. ${ }^{41}$

Also, low resistance of the paravertebral muscles to fatigue is common in patients with chronic low back pain. ${ }^{41,42}$ These patients avoid movements in their daily life for fear of pain, kicking off a cycle of disuse of this musculature that can evolve into muscle hypotrophy and gradually into a worsening of their profile of progressive low back pain. ${ }^{43}$

\section{FINAL CONSIDERATIONS}

Our findings in this review show the important role of two muscle groups (ischiotibial and paravertebral) and the correlation of their dysfunction to low back pain.

As regards the paravertebral muscle group, the weakness of these muscles is related to postural changes, where an imbalance in the muscular chain between the flexor and extensor muscles of the torso is a determining factor for the development of low back pain, showing the importance of the strengthening of this muscular group as a means of treatment and prevention of low back pain.

The ischiotibial muscle group plays a role in the balance between hip and knee movements, in which the shortening of these muscles is closely related to low back pain. In our review, we found that stretching the ischiotibial muscle group helps reduce lumbar pain.

All the authors declare that there are no conflicts of interest regarding this article. 
CONTRIBUTIONS OF THE AUTHORS: The author made significant individual contributions to the preparation and development of the manuscript, being solely responsible for the research, preparation, and intellectual contribution of the study.

\section{REFERENCES}

1. Rozenberg S. Chronic low back pain: definition and treatment. Rev Prat. 2008;58(3):265-72.

2. Meirelles ES. Lombalgia: como diagnosticar e tratar. Rev Bras Med. 2003;60:111-9.

3. Helfenstein Junior M, Goldenfum MA, Siena C. Lombalgia ocupacional. Rev Assoc Med Bras. 2010;56(5):583-9.

4. Kolyniak I, Cavalcanti S, Aoki M. Avaliação isocinética da musculatura envolvida na flexão e extensão do tronco: efeito do método Pilates. Rev Bras Med Esporte. 2004:10(6):487-90.

5. Sole G, Hamrén J, Milosavljevic S, Nicholson H, Sullivan SJ. Test-retest reliability of isokinetic knee extension and flexion. Arch Phys Med Rehabil. 2007;88(5):626-31.

6. Toscano JJO, Egypto EP. A influência do sedentarismo na prevalência de lombalgia. Rev Bras Med Esporte. 2001;7(4):132-7.

7. Vialle LR, Vialle EM, Henao JES, Giraldo G. Hérnia discal lombar. Rev Bras Ortop. 2010;45:17-22.

8. Apeldoorn AT, Ostelo RW, van Helvoirt H, Fritz JM, Knol DL, van Tulder MW, et al. A randomized controlled trial on the effectiveness of a classification-based system for subacute and chronic low back pain. Spine (Phila Pa 1976). 2012;37(16):1347-56.

9. Aydin S, Kucukyuruk B, Yildirim H, Abuzayed B, Bozkus H, Vural M. Acute formation of lumbar discal cyst: what is the mechanism? J Neurosurg Sci. 2010;54(4):149-52.

10. Sato K, Nimura A, Yamaguchi K, Akita K. Anatomical study of the proximal origin of hamstring muscles. J Orthop Sci. 2012:17(5):614-8.

11. Aydin S, Abuzayed B, Yildirim H, Bozkus H, Vural M. Discal cysts of the lumbar spine: report of five cases and review of the literature. Eur Spine J. 2010;19(10):1621-6.

12. Yu PF, Jiang FD, Liu JT, Jiang H. Outcomes of conservative treatment for ruptured lumbar disc herniation. Acta Orthop Belg. 2013;79(6):726-30.

13. Huang SR, ShiYY, Zhan HS. Individual stratification diagnosis of lumbar intervetebral disc herniation. Zhongguo Gu Shang. 2012;25(3):228-32.

14. Wang $X$, Zeng J, Nie H, Chen G, Li Z, Jiang H et al. Percutaneous endoscopic interlamina discectomy for pediatric lumbar disc herniation. Childs Nerv Syst. 2014;30(5):897-902.

15. Wetler $E$, Barros JF, Rocha Jr VA. O tratamento conservador através da atividade física na hérnia de disco lombar. Revista Digital-Buenos Aires - Año 10 - No.70-Marzo de 2004 Disponível em: http://www.efdeportes.com/efd70/hernia.htm

16. Yahia A, Ghroubi S, Kharrat O, Jribi S, Elleuch M, Elleuch MH. A study of isokinetic trunk and knee muscle strength in patients with chronic sciatica. Ann Phys Rehabil Med. 2010:53(4):239-44.

17. Sato T, Koizumi M, Kim JH, Kim JH, Wang BJ, Murakami G, Cho BH. Fetal development of deep back muscles in the human thoracic region with a focus on transversospinalis muscles and the medial branch of the spinal nerve posterior ramus. J Anat. 2011;219(6):756-65.

18. Suri P, Rainville J, Kalichman L, Katz JN. Does this older adult with lower extremity pain have the clinical syndrome of lumbar spinal stenosis? JAMA. 2010;304(23):2628-36.

19. Mukai Y, Takenaka S, Hosono N, Miwa T, Fuji T. Intramuscular pressure of the multifidus muscle and low-back pain after posterior lumbar interbody fusion: comparison of mini-open and conventional approaches. J Neurosurg Spine. 2013;19(6):651-7.

20. Carneiro JAO, Santos-Pontelli TEG, Colafêmina JF, Carneiro AAO, Ferriolli E. Um estudo piloto na avaliação das estratégias posturais em jovens e idosos usando um sistema eletromagnético tridimensional. Braz J Otorhinolaryngol. 2013;79(2):219-25.

21. Aulisa L, Pitta L, Aulisa AG, Mastantuoni G, Pola E, Leone A. Lumbar nerve root "walled" by a calcified herniated mass in a young patient. Childs Nerv Syst. 2003;19(5-6):384-6.

22. Oestergaard LG, MariboT, Bünger CE, Christensen FB. The Canadian Occupational Performance Measure's semi-structured interview: its applicability to lumbar spinal fusion patients. A prospective randomized clinical study. Eur Spine J. 2012;21(1):115-21.
23. Clemente-Fuentes RJ, Pickett $H$, Carney M. Clinical inquiry. How can pregnant women safely relieve low-back pain? J Fam Pract. 2013:62(5):260-8.

24. Melhado S, Solder Z. Lombalgia na gravidez: análise entre as gestantes no último trimestre de gestação. Rev Femina. 2004;32:647-52.

25. Hides JA, Stanton WR, McMahon S, Sims K, Richardson CA. Effect of stabilization training on multifidus muscle cross-sectional area among young elite cricketers with low back pain. J Orthop Sports Phys Ther. 2008;38(3):101-8.

26. Santos C F, Domingues CA. Avaliação pré e pós-mobilização neural para ganho de ADM em flexão do quadril por meio do alongamento dos isquiotibiais. Conscientiae Saúde. 2008;7(4):487-96.

27. Glaner MFA importância da aptidão física relacionada à Saúde. Rev Bras Cineantropom Desempenho Hum. 2003;5(2):75-85.

28. Martins R, Silva JLP. Tratamento da lombalgia e dor pelvica posterior na gestação por um método de exercícios. Rev Bras Ginecol Obstet. 2005;27(5):275-82.

29. Candotti C, Noll M. Cruz M. Prevalência de dor lombar e os desequilíbrios musculares em manicures. Rev Arq Mov. 2010:6:125-40.

30. Neto Junior J, Pastre CM, Monteiro HL. Alterações posturais em atletas brasileiros do sexo masculino que participaram de provas de potência muscular em competições internacionais. Rev Bras Med Esporte. 2004;10(3):195-8.

31. Mann L, Kleipaul JF, Teixeira CS. Konopka CK. Dor lombo-pélvico e exercício físico durante a gestação. Fisioter Mov. 2008;21(2):99-105.

32. Shuback B, Hooper J, Salisbury L. A comparision of a self- -stretch incorporating proprioceptive neuromuscular facilitation components and a therapist-applied PNF-technique on hamstring flexibility. Physiotherapy. 2004;90:151-7.

33. Hettinga DM, Jackson A, Moffett JK, May S, Mercer C, Woby SR. A systematic review and synthesis of higher quality evidence of the effectiveness of exercise interventions for nonspecific low back pain of at least 6 weeks' duration. Phys Therap Reviews. 2007:12(3):221-32.

34. Oliveira VC, Bicalho LI, Soares TB, Dornellas RS. Estabilidade articular da coluna vertebral: teorias contemporâneas e novos paradigmas. Fisioter. 2009;10(4):284-9.

35. Barr KP, Griggs M, Cadby T. Lumbar stabilization: a review of core concepts and current literature, part 2. Am J Phys Med Rehabil. 2007:86(1):72-80.

36. Danneels LA, Vanderstraeten GG, Cambier DC, Witvrouw EE, De Cuyper HJ. CT imaging of trunk muscles in chronic low back pain patients and healthy control subjects. Eur Spine J. 2000;9(4):266-72.

37. Longato MW, Catro PR, Keller KCR, Romanovitch DI. Efeito do isostretching no equilíbrio de indivíduos amputados: um estudo de caso. Fisioter Mov. 2011;24(4):689-96.

38. Hodges PW, Moseley GL, Gabrielsson A, Gandevia SC. Experimental muscle pain changes feedforward postural responses of the trunk muscles. Exp Brain Res. 2003;151(2):262-71.

39. Hodges PW, Moseley GL. Pain and motor control of the lumbopelvic region: effect and possible mechanisms. J Electromyogr Kinesiol. 2003;13(4):361-70.

40. Cholewicki J, van Dieën JH, Arsenault AB. Muscle function and dysfunction in the spine. J Electromyogr Kinesiol. 2003;13(4):303-4.

41. Macedo CSG, Debiagi PCA, Marçola F. Efeito do isostretching na resistência muscular de abdominais, glúteo máximo e extensores de tronco, incapacidade e dor em pacientes com lombalgia. Fisioter Mov. 2010;23:113-20.

42. Costa D, Palma A. O efeito do treinamento contra resistência na síndrome da dor lombar Rev Port Cien Desp. 2005;5(2):224-34.

43. Reiman MP, Weisbach PC, Glynn PE. The hips influence on low back pain: a distal link to a proximal problem. J Sport Rehabil. 2009;18(1):24-32. 